\title{
A financeirização das políticas sociais e da saúde no Brasil do século XXI: elementos para uma aproximação inicial *
}

\author{
José Antonio de Freitas Sestelo * \\ Artur Monte Cardoso ${ }^{* * *}$ \\ Ialê Falleiros Braga ${ }^{* * * *}$ \\ Leonardo Vidal Mattos ${ }^{\text {****** }}$ \\ Lucas Salvador Andrietta ${ }^{* * * * * * *}$
}

\begin{abstract}
Resumo
O objetivo do artigo é cotejar a literatura sobre financeirização e compreender sua expressão no debate sobre as políticas sociais brasileiras, especialmente na saúde, entendendo a dominância financeira como novo modo de ser do regime global de produção de riqueza. Enfatiza-se evidências da financeirização, seus conceitos e sua expressão no caso brasileiro. Aponta-se lacunas em estudos atuais sobre o welfare state e possíveis aproximações com o tema da financeirização. Destaca-se estudos com essa proposta no Brasil, identificando tendências na assistência social, previdência, habitação, educação e, particularmente, na saúde. A revisão evidencia a relevância do tema e os limites das abordagens setoriais no Brasil. Postula-se que, na saúde, a mudança no padrão setorial de acumulação acompanhou o aprofundamento da financeirização. Essa nova configuração debilita abordagens restritas ao orçamento público e ao papel do Estado, e solicita seu aprimoramento por pesquisas empíricas sobre a conformação e a agenda política dos agentes privados.
\end{abstract}

Palavras-chave: Financeirização; Política social; Welfare state; Políticas de saúde.

\section{Abstract \\ The financialization of social and health policy in Brazil in the $21^{\text {st }}$ century: elements for beginning the process}

The objective of this article is to review the literature on financialization and to: show how it is expressed in the debate on Brazilian social policies, especially Healthcare, assuming financial dominance as a new way of being of the global wealth production regime. It emphasizes evidence of financialization, its concepts and its expression in the Brazilian case. Gaps are pointed out in current

* Artigo recebido em 6 de abril de 2017 e aprovado em 18 de setembro de 2017. Todos os autores estão ligados ao Grupo de Pesquisa e Documentação sobre o Empresariamento da Saúde Henry Jouval Jr. GPDES/Universidade Federal do Rio de Janeiro (UFRJ), Rio de Janeiro, RJ, Brasil.

** Pesquisador do Grupo de Pesquisa e Documentação sobre o Empresariamento da Saúde Henry Jouval $J r$. GPDES/Universidade Federal do Rio de Janeiro - UFRJ. E-mail: sestelo.jose@ gmail.com.

*** Doutorando do Instituto de Economia da Universidade Estadual de Campinas (Unicamp/IE), Campinas, SP, Brasil. E-mail: artumoca@ gmail.com.

**** Da Escola Politécnica de Saúde Joaquim Venâncio EPSJV/Fiocruz, Rio de Janeiro, RJ, Brasil. E-mail: ialefalleiros@gmail.com.

****** Pesquisador do Grupo de Pesquisa e Documentação sobre o Empresariamento da Saúde Henry Jouval $J r$... Rio de Janeiro, RJ, Brasil. Endereço eletrônico: leovmattos@ gmail.com.

****** Doutorando do Instituto de Economia da Universidade Estadual de Campinas (Unicamp/IE), Campinas, SP, Brasil. Endereço eletrônico: lucasandrietta@gmail.com. 
studies on the welfare state and possible approaches to the topic of financialization. We highlight studies with this proposal in Brazil, identifying trends in social assistance, pensions, housing, education and, particularly, healthcare. The review highlights the relevance of the theme and the limits of sectoral approaches in Brazil. It is postulated that, in the healthcare sector, changes in the pattern of accumulation followed the spread of financialization. This new context weakens approaches restricted to public budget issues and the role of the state, and demands to be improved by empirical research on private agent's frame and political agenda.

Keywords: Financialization; Social policy; Welfare state; Health policies.

JEL B50, E60, G00, H50, I18.

\section{Introdução}

O estudo da financeirização destacou-se como tema relevante nas economias dos países centrais a partir do final do século XX quando evidências empíricas recorrentes passaram a validar alguns conceitos e desenvolvimentos teóricos elaborados previamente no campo da Economia Política.

Neoliberalismo, globalização e financeirização passaram progressivamente a compor um léxico de ampla circulação, não apenas no âmbito da Ciência Econômica, mas na alçada de outros espaços disciplinares nas Ciências Sociais. Da mesma forma, pode-se dizer que o tema passou da periferia para o mainstream do campo acadêmico enquanto o seu campo de observação empírica se ampliou do centro para os países da periferia do sistema.

Há estudos de revisão publicados depois do ano 2000 que discutem uma variedade de abordagens consolidadas nos limites das Ciências Econômicas, nas teorias sobre administração de companhias e negócios e mesmo em estudos antropológicos sobre o espalhamento da financeirização na vida cotidiana da sociedade (Van Der Zwan, 2014).

Há também desenvolvimentos que destacam as peculiaridades do fenômeno na dimensão macroeconômica de países periféricos como o Brasil (Bruno et al., 2011) e a sua expressão nas políticas sociais de governo (Fine, 2009).

Nesse particular, as abordagens mais incidentes adotam modelos causais que focam em ações de governo direcionadas para agentes econômicos privados como empresas e pessoas físicas por meio de políticas sociais de Estado.

Tais contribuições são fundamentais para a compreensão de um aspecto importante no estudo da financeirização e há evidências empíricas consideráveis a seu favor. Entretanto, há outras abordagens que partem de modelos causais multidirecionais, admitindo a influência mútua e recíproca entre ações institucionais de governos, empresas e demais agentes econômicos e sociais. Suas premissas são baseadas precisamente no entendimento de que a dominância financeira se constitui em um novo modo de ser da riqueza global indissociável das atividades de produção 
industrial, de serviços ou da esfera de manutenção e reprodução da vida social em geral e não uma qualidade extrínseca incorporada em maior ou menor grau pelos variados setores da vida econômica e social a partir apenas de ações originadas na esfera institucional.

A seleção de trabalhos que dispomos a seguir visa reconstituir, ainda que de forma não exaustiva, a trajetória de construção do pensamento recente sobre financeirização a partir de uma moldura mais abrangente em direção à sua expressão nas políticas sociais e na assistência à saúde em particular.

Ao final, considerando o conjunto do material reunido e as evidências mais diretas de expressão da financeirização em espaços importantes da assistência à saúde no Brasil, tecemos considerações sobre novas possibilidades de abordagem para a investigação desse tema.

\section{Financeirização como novo padrão sistêmico de riqueza}

Em geral, a financeirização ou o capitalismo com dominância financeira são associados à ascensão das finanças no capitalismo, o que se manifesta na definição abrangente de G. Epstein, que podemos tomar como referência de forma inicial e provisória: increasing role of financial motives, financial markets, financial actors and institutions in the operation of the domestic and international economies (Epstein, 2005, p. 3). Para Guttmann, a financeirização se desdobra segundo três facetas principais: a maximização do valor ao acionista como norma de gestão das empresas, o descolamento dos vínculos entre lucros (usados para operações de fusões e aquisições, distribuição e aquisição de ativos financeiros) e investimentos (tendo como resultado a redução das taxas de crescimento) e um processo de redistribuição de renda com crescente peso das rendas do capital sobre o trabalho, e dentre elas, juros, dividendos e comissões (Guttmann, 2008, p. 12-14).

De fato, nas últimas quatro ou cinco décadas, assistiu-se a uma série de fenômenos que conferem uma nova qualidade ao papel das finanças no capitalismo. Este processo está diretamente relacionado à crise do arranjo de Bretton Woods, com a transição para um sistema financeiro internacionalizado e a ascensão das empresas transnacionais, bem como no esforço que os Estados Unidos realizaram para reafirmar a hegemonia da sua moeda, do seu mercado financeiro, do seu padrão produtivo e dos seus interesses estratégicos (Tavares; Melin, 1997). Um conjunto de mudanças deliberadas, normalmente associadas ao neoliberalismo, promoveu a remoção de barreiras entre compartimentos financeiros separados, a desintermediação e desregulamentação dos mercados financeiros e a formação de um espaço mundial integrado, hierarquizado, sem instâncias de regulação e controle, marcado por inovações financeiras e unificado pelos seus operadores, com destaque para investidores institucionais (Chesnais, 1998). A dinâmica macroeconômica ficou 
dependente de ciclos de liquidez irradiados do centro, com forte importância do efeito-riqueza, resultando em maior instabilidade e propensão a crises derivadas dos ciclos de inflação e deflação de ativos (Coutinho; Belluzzo, 1998). O Estado tende a sancionar e promover tal processo, seja por meio do uso da dívida pública para alimentar o circuito financeiro, seja pela responsabilidade de resgatar o sistema financeiro em crise, como ficou patente no estopim dos eventos transcorridos entre 2008-2009 (Braga, 2009).

Tais mudanças de qualidade no capitalismo nos remetem à definição de financeirização elaborada por Braga (1985) como um padrão sistêmico de definição, gestão e realização da riqueza $a^{6}$, em que a busca por gerar e valorizar recursos líquidos torna-se a lógica geral do modo de produção capitalista. Remete-se, aqui, às categorias desenvolvidas por Marx para compreender o desdobramento do capital monetário em capital portador de juros e capital fictício, revelador de como a lógica financeira busca reduzir a relação social do capital ao simplificado circuito dinheiromais dinheiro (D-D’) (Marx, 1985 [1894]).

É importante destacar que não se trata, nesse caso, de mera aplicação de conceitos apriorísticos (como se fosse um desdobramento imediato), mas da síntese de um novo padrão histórico, desenvolvido sob condições específicas. Isso se faz com recurso às contribuições fundamentais de Marx e também de R. Hilferding (1973 [1910]), que entendem o capital financeiro como a fusão de formas parciais do capital, e à contribuição de J. Hobson (1996 [1894]), que vê na articulação de trustes, companhias ferroviárias e bancos dos EUA a origem de um poder puramente financeiro. Não se trata, justamente, de considerar a financeirização uma distorção, deturpação ou desvio de rota do que poderia ser entendido como funções produtivas do capitalismo (Braga, 2015), mas da realização, sob certas condições históricas, do movimento essencial da lógica do capital de forma abrangente e disseminada:

Trata-se de um padrão sistêmico porque a financeirização está constituída por componentes fundamentais da organização capitalista, entrelaçados de maneira a estabelecer uma dinâmica estrutural segundo princípios de uma lógica financeira geral. Neste sentido, ela não decorre apenas da práxis de segmentos ou setores - o capital bancário, os rentistas tradicionais - mas, ao contrário, tem marcado as estratégias de todos os agentes privados relevantes, condicionado a operação das finanças e dispêndios públicos, modificado a dinâmica macroeconômica. Enfim, tem sido intrínseca ao sistema tal como ele está atualmente configurado (Braga, 1997, p. 196).

(6) A dominância financeira - a financeirização - é expressão geral das formas contemporâneas de definir, gerir e realizar riqueza no capitalismo. Por dominância financeira apreende-se, inclusive conceitualmente, o fato de que todas as corporações (...) têm em suas aplicações financeiras, de lucros retidos ou de caixa, um elemento central do processo de acumulação global de riqueza” (Braga, 1993, p. 26). 
Enquanto lógica geral e sistêmica, a financeirização tende a se desdobrar em diversos aspectos da vida econômica e social que estiveram relativamente à parte das atividades financeiras, no sentido estrito. Certamente um dos aspectos mais polêmicos é como as empresas não-financeiras (ENFs) se posicionam neste processo. A ideia de Maximizing Shareholder Value (Lazonick; O’Sullivan, 2000) acabou despertando a interpretação de que a financeirização teria sido imposta de fora para dentro, "submetendo" e "fragilizando" as empresas (Plihon, 2005), o que levaria ao enfraquecimento do lado real do investimento e do crescimento (Stockhammer, 2004; Crotty, 2005; Orhangazi, 2008). É necessário, contudo, enfatizar a participação ativa das ENFs neste processo (Serfati, 1998), o que pode ser visto na incorporação das atividades financeiras ao rol de atividades da função objetivo da corporação (Braga, 1997, p. 215-217). Igualmente, podemos entender as empresas transnacionais (ETNs) como categorias em si, típicas deste período, que as torna grupos financeiros com atividades produtivas, comerciais e de serviços (Serfati, 2011), fato materializado na forma holding e no uso de diversas estratégias de enxugamento, valorização e crescimento por meio de fusões e aquisições (F\&A), terceirização e deslocalização, operações em paraísos fiscais para evitar impostos, etc. Em especial, a ênfase no uso do outsourcing e offshoring conduziu ao desenvolvimento de cadeias globais de valor, que também possuem um componente de geração e uso de recursos financeiros (Milberg, 2008).

A financeirização, contudo, não se expressa e se concretiza da mesma forma em todos os países e em todos os setores. Há uma grande diferença na sua expressão entre os países centrais (normalmente demarcada pelos anglo-saxões, demais europeus e alguns asiáticos) e entre esses e os países periféricos do sul global. A despeito da existência de uma crescente literatura sobre financeirização em países ditos emergentes (Bonizzi, 2013; Karwowski; Stockhammer, 2017), boa parte dos estudos e dos paradigmas do que se entende por financeirização são baseados sobretudo nos Estados Unidos, onde há maior disponibilidade de dados e onde se gerou maior produção técnica ou acadêmica. Daí a necessidade de buscar a especificidade deste padrão de riqueza na periferia.

É sob o contexto do esgotamento da substituição de importações e do estabelecimento de uma nova dependência, nos anos 1980, que as atividades financeiras ganham outra qualidade no Brasil (Furtado, 1982). Com a estatização da dívida externa, o ajuste promovido pelo FMI impunha ao Estado se financiar em moeda nacional para adquirir as divisas dos exportadores, o que alimentou um circuito de financeirização precoce, dadas as condições de instabilidade macroeconômica, recessão e inflação crescentes (Carneiro, 2002). Os setores líquidos da economia refugiaram-se nos ativos financeiros, especialmente lastreados em moeda indexada, e as empresas não-financeiras desenvolveram um ajuste para preservar a rentabilidade, por meio da gestão de markups, da desalavancagem e de 
aplicações financeiras e operações patrimoniais, como aquisições ou compra de participações societárias (Belluzzo; Almeida, 2002).

A racionalidade econômica baseada na acumulação financeira, lastreada pela dívida pública, e em estratégias defensivas se aprofundou nas décadas seguintes. A reincorporação do Brasil aos fluxos financeiros internacionais foi acompanhada pela abertura financeira e comercial, o que amplificou a sua vulnerabilidade externa. O arranjo de políticas do Plano Real concretizou isso, ao basear a estabilização em uma apreciação cambial e juros altos, que se tornou inviável depois da sequência de crises na periferia (México, Ásia, Rússia) e do custo crescente do endividamento externo. O regime de metas e o tripé macroeconômico de 1999 em diante reciclou a vulnerabilidade com o câmbio flexível, mantendo a importância da dívida, mantida agora por um superávit primário institucionalizado.

Do ponto de vista monetário, a especificidade brasileira reside na sua posição periférica na hierarquia de moedas e na inconversibilidade (Andrade; Prates, 2013) além da forte exposição à especulação internacional no mercado futuro de câmbio (Kaltenbrunner, 2010; Rossi, 2016). A tendência, sempre presente, para apreciação e instabilidade cambial abriu espaço para grandes operações com derivativos, inclusive de empresas não-financeiras sem fins de hedge (Farhi; Borghi, 2009; Rossi Júnior, 2013). Do ponto de vista da divisão internacional do trabalho, a instabilidade, a apreciação do Real e o peso da financeirização baseada na dívida pública parecem condicionar e sancionar um longo processo de especialização regressiva e desindustrialização, ainda que haja grande polêmica sobre tais relações (Gaulard, 2015; Feijó; Lamônica; Lima, 2016). Não é possível ignorar a participação ativa de grupos empresariais e fundos de investimento na financeirização brasileira, com desdobramentos para todos os setores da economia e na relação com os serviços públicos, financiamento do investimento, etc. As políticas sociais, como veremos a seguir, passam a ser combinadas e recombinadas sob tais determinantes, e o papel das empresas que atuam ou buscam atuar neste setor, em relação com o Estado, é de vital importância para entender a especificidade brasileira.

\section{Política social e welfare state no capitalismo contemporâneo}

A política social, enquanto intervenção do Estado nas questões sociais (Fleury, 1994) e fenômeno intrínseco ao desenvolvimento capitalista, tem sido objeto de estudo e debate entre as mais diversas correntes da Ciência Política, da Sociologia e da Economia. A emergência dos direitos sociais e das estruturas de proteção social guarda relação com a transição das sociedades para a modernidade e com a incorporação de novas atribuições ao Estado. A política social passa a ser elemento-chave para compreensão do papel político e econômico do Estado moderno nos mais diversos temas de investigação, que vão desde a própria natureza do Estado capitalista até os processos de industrialização, modernização, e 
construção dos Estados nacionais, passando pelas consequências das políticas sociais nas esferas da produção e reprodução social e nos conflitos entre as classes sociais.

A partir das análises sobre a emergência das políticas sociais na Europa, especialmente no período pós-guerra, surge o conceito de welfare state, ou Estado de Bem-Estar Social, com variações teóricas entre diferentes autores (Fleury, 1994).

Uma das formulações mais difundidas, considera o welfare state como forma de articulação dos conflitos distributivos (Esping-Andersen, 1990; 1991). O autor assinala os critérios que definem e os fatores que teriam relação causal com o welfare state:

(...) definir os welfare state tem a ver com a qualidade dos direitos sociais, com a estratificação social e com o relacionamento entre Estado, mercado e família. (...) Três fatores seriam importantes: a natureza da mobilização de classe (principalmente da classe trabalhadora), as estruturas de coalizão política de classe; e o legado histórico da institucionalização do regime (EspingAndersen, 1991, p. 111).

As diversas condições políticas e econômicas que viabilizaram os welfare state nos países centrais do capitalismo e que tiveram influência direta na construção da sua teoria são sintetizadas por Fiori (1997). Destacamos a generalização do paradigma fordista; o consenso em torno das políticas keynesianas, como o pleno emprego; a manutenção de um ritmo crescimento econômico constante e sem precedentes que permitiu que os ganhos fiscais fossem alocados por coalizões políticas socialmente orientadas; o ambiente econômico global criado pelos acordos de Bretton-Woods; e o avanço das democracias partidárias de massa que possibilitou um aumento do peso das reivindicações dos trabalhadores; e no plano geopolítico, a polarização presente na Guerra Fria, que mantinha vivo o fantasma do socialismo.

Todavia, as transformações no modo de ser do capitalismo verificadas nas últimas décadas alteraram drasticamente o panorama. Fiori (1997) considera que os aspectos mais relevantes dessas mudanças que afetariam a viabilidade dos welfare state, tendo a globalização econômica como epicentro, seriam: o consenso estabelecido contra as políticas keynesianas e as ideias de crescimento e pleno emprego, dando lugar à estabilidade e ao equilíbrio macroeconômico; o paradigma fordista substituído pelas ideias de flexibilização e segmentação dos processos produtivos (toyotismo); o crescimento do desemprego e alteração da composição do trabalho; a polarização entre mercados primários ou globalizados e secundários de trabalho fragmentado, com consequente enfraquecimento dos sindicatos; o crescimento desacelerado em função de políticas deflacionistas; a substituição do contexto da Guerra Fria pela ascensão dos blocos regionais organizados em torno dos imperativos econômicos-monetários; a diminuição da possibilidade de divergência no plano das políticas econômicas. 
Assim, a generalização da abordagem dos regimes de welfare state teria uma limitação histórica, dado que acaba transpondo os pressupostos das condições econômicas e políticas específicas de um seleto grupo de sociedades no momento pós-guerra, cenário que se alterou completamente; e uma limitação metodológica, na medida em que a comparação acrítica entre países em diferentes estágios de desenvolvimento estaria enviesada por condições históricas e características políticas, econômicas e sociais muito distintas (Fleury, 1994; Fiori, 1997; Fine, 2014).

Para além da teoria, a metodologia comparativa proposta por EspingAndersen (1991) com a proposição de tipologias para três diferentes regimes de welfare state (liberal, conservador e social-democrata) se desdobrou em uma extensa produção que hegemonizou os estudos sobre políticas sociais nas últimas décadas. Esta literatura tem sido alvo de críticas de diversos autores, sintetizadas em alguns trabalhos (Bambra, 2006; Powell; Barrientos, 2011; Fine, 2014).

Novas tipologias e modelos híbridos foram sendo adaptados ou criados para outros contextos, na maioria das vezes sem muitas preocupações com a aplicabilidade a outras realidades, a diferentes setores e sem renovação do debate teórico. Assim, teríamos hoje uma grande produção de evidências empíricas, porém sem um substrato teórico que se aproxime aos resultados (Powell; Barrientos, 2011). A classificação teria se tornado um fim em si mesmo, com baixo potencial explicativo sobre as transformações em curso, desarticulada de determinantes mais gerais e das especificidades de cada contexto.

Para os estudos que se proponham a enfrentar os desafios teóricos e metodológicos atuais sob os referenciais da economia política, destacamos cinco eixos transversais quem vem sendo abordados na literatura.

O primeiro, parte do diagnóstico de que a característica contemporânea mais marcante das políticas sociais seria a diversidade de formatos e resultados e a multiplicidade de fatores que influenciam em sua elaboração entre diferentes países, setores, programas, em diferentes circunstâncias e períodos históricos. Para possibilitar considerações teóricas mais apropriadas, as análises sobre políticas sociais, ao invés de induzir uma homogeneização e uniformização (entre setores e países), devem abarcar e explicar a diversidade. Captá-la e refletir sobre ela passaria pela especificação do contexto, pela especificação dos possíveis determinantes/influências gerais e como estes determinantes gerais interagem com as especificidades empiricamente observáveis (Fine, 2014).

O segundo eixo consiste em situar as políticas sociais em sua relação com a produção e a reprodução social (Fleury, 1994). Assim, o desempenho econômico, a globalização da produção, os níveis de emprego e composição dos mercados de trabalho, os salários, as condições de trabalho, as desigualdades de renda, gênero, 
raça e no acesso ao consumo (e os determinantes gerais que influenciam estas variáveis, incluindo a financeirização) já seriam por si só fatores que moldam as condições às quais a política social precisa responder e, em última análise, reproduzir. Além disso, a própria política social é também uma esfera de geração e acumulação de riqueza.

O terceiro eixo consiste em equilibrar a importância da dimensão da transferência de renda (pensões e benefícios ligados à seguridade social, por exemplo) com a dimensão dos serviços (saúde, educação etc.). Jensen (2011) mostra que os estudos sobre welfare state têm focado majoritariamente na primeira. Porém, estas dimensões teriam grandes diferenças qualitativas em função de seus modos de produção e dinâmica de funcionamento distintos. Segundo o autor, os estudos sobre os serviços geralmente se restringem ao desenho específico de programas; a comparações entre países buscando analisar se os serviços se encaixam em diferentes regimes de welfare; tentativas de estabelecer relações entre os tipos de transferências e a provisão de serviços.

O quarto e último eixo consiste em situar as políticas sociais em movimentos multidimensionais e contraditórios, com tendências conflitantes ao invés de oposições lineares, considerando como essas tensões são resolvidas no contexto atual, ao invés de reduzi-las a dualismos (mais ou menos estratificação, desmercadorização, residualismo, seletividade) (Fine, 2014).

Dadas as transformações atuais do capitalismo e do papel do Estado, sendo a política social um elemento constitutivo de ambos e ainda uma arena importante de materialização dos conflitos distributivos, é de grande relevância buscar compreender como os padrões sistêmicos influenciam e são influenciados pelas políticas sociais, e que diferentes funções ambos cumprem em novos arranjos de produção e reprodução social, investigando, por exemplo, que caminhos podem ser explorados para abordar as relações entre financeirização e política social.

\section{Financeirização da política social}

Observa-se atualmente a baixa incidência do tema da financeirização na produção acadêmica sobre política social e welfare state. Segundo Fine (2014), essa ausência seria, por um lado, sintomática da insuficiência no entendimento da relação entre globalização e financeirização no estudo das políticas sociais. Por outro lado, seria limitante, na medida em que restringe a compreensão da diversidade de resultados entre países e setores, apesar da existência de determinantes comuns, entre eles a financeirização.

Este autor aponta que a financeirização pode impactar nas políticas sociais por dois caminhos distintos. O primeiro, abordado anteriormente, é a influência direta sobre as condições da produção e da reprodução social. O segundo é o impacto 
direto no conteúdo, forma e processo de elaboração das políticas sociais, principalmente devido a sua forte associação com os imperativos da globalização e ao neoliberalismo.

É importante esclarecer de que forma financeirização e neoliberalismo enquanto categorias analíticas se articulam do ponto de vista das políticas sociais. Sendo a financeirização o novo padrão sistêmico de gestão, definição, e realização da riqueza (Braga, 1985), o neoliberalismo deve ser entendido para além da materialização ideológica e política do poder de classe, mas como um momento histórico do desenvolvimento capitalista que emerge após o boom do pós-guerra, que é sustentado pela financeirização enquanto padrão sistêmico, ainda que não possa ser reduzido a ela (Fine; Saad-Filho, 2017).

Como consequência, é necessário compreender a relação entre Estado neoliberal e as políticas sociais, frequentemente vistos como polos antagônicos. Para Hartman (2005), apesar de retóricas distintas, o welfare state é uma das condições de existência do neoliberalismo, estando no contexto atual em consonância com processos como a flexibilização do trabalho e o aumento das desigualdades. Parece mais adequada a visão que situa o Estado e as políticas sociais como elementos constitutivos das condições, determinantes e contradições do capitalismo contemporâneo, pois evita falsas contradições como aquelas que opõe o princípio da contenção fiscal à oferta de políticas sociais.

Essa visão é corroborada por Bayliss et al. (2015), que especifica algumas características desse novo papel do Estado, relacionado às mudanças nos pressupostos do pacto entre capital e trabalho com fortalecimento das finanças e menor quantidade de recursos destinados ao trabalho; à reconfiguração do escopo das políticas sociais, tendendo a um maior residualismo e suprimindo princípios como redistribuição ou equidade; às privatizações na provisão, que não reduz o tamanho do Estado em si, mas muda sua posição de provedor para regulador; e a mudanças institucionais nas relações entre organizações estatais, mercado e sociedade, com fortalecimento das autoridades locais.

Fine (2014) aponta algumas possíveis vertentes para o estudo das relações entre financeirização e políticas sociais. Uma primeira associa a financeirização à pressão das políticas macroeconômicas neoliberais sobre o orçamento público. Por um lado, prega uma restrição da expansão (ou corte) dos gastos sociais e por outro propõe implementar mecanismos de transferência do orçamento existente para setores privados ou financeiros, de maneira direta ou indireta. Este aspecto tem grande relevância e tem sido explorado na literatura, porém acaba limitando a influência da financeirização apenas à esfera orçamentária.

Uma segunda vertente associa a financeirização ao fortalecimento a nível local e internacional de elites financeiras, ou ligadas ao setor financeiro, com 
crescente poder e influência sobre a definição das políticas públicas. O papel destas elites tem sido pouco estudado, especialmente no que se refere às políticas sociais. Todavia, um cuidado deve ser tomado com visões que atribuem ao Estado apenas o papel de gestor dos interesses de uma burguesia financeira (p. 25, 27).

A terceira vertente associa a financeirização à transformação no processo de formulação de políticas sociais (policy making), através da prevalência dos imperativos do neoliberalismo na correlação de forças atuantes nesta esfera. $\mathrm{O}$ resultado se expressa na forma como a própria governança da elaboração de políticas sociais passa a ser tratada, introduzindo novas formas de gestão no setor público, promoção da descentralização e da participação, associadas a um protagonismo de agências internacionais (p. 27).

A quarta vertente associa a financeirização à promoção do capital privado no âmbito das políticas sociais, de maneira direta ou indireta. O incentivo e promoção das privatizações poderia não apenas mercantilizar a provisão pública ao inserir o setor privado em áreas anteriormente exclusivas do Estado, mas também transformá-las em ativos a serem incorporados no mercado financeiro, como, por exemplo, nos casos da habitação e previdência (Bayliss et al., 2013). De maneira indireta, isso poderia ocorrer mesmo quando o serviço não é transformado diretamente em ativo financeiro, uma vez que com a privatização há também a criação de novos fluxos de recursos e receitas anteriormente inexistentes que são absorvidos pelo setor privado e podem ser consolidados em ativos financeiros, especialmente quando os serviços passam a ser prestados por grandes empresas inseridas em uma dinâmica mais geral de acumulação financeirizada.

Todavia, a relação entre privatização e financeirização deve ser vista com cautela para evitar automatismos, uma vez que, dentro das especificidades de cada setor, a extensão da influência da financeirização pode se dar de maneira diversa a depender do tipo de ativo/atividade em questão. Além disso, os graus de vinculação/dependência contínua desses ativos com suas atividades não financeiras originárias também são diversos nos diferentes setores das políticas sociais. Portanto, o que vale para a previdência, por exemplo, pode não valer para o setor educação, em função do caráter da provisão em cada setor (Fine, 2014).

Esta última vertente é de especial interesse para o estudo da assistência à saúde, uma vez que liga mais diretamente a política social ao processo de acumulação capitalista, abrindo caminho para investigações sobre suas relações e ajudando a decifrar a inserção mais característica da política social na dinâmica contemporânea de produção e reprodução social.

Uma hipótese de trabalho seria a de que a política social ocuparia um novo papel no processo de acumulação capitalista em um contexto de aumento da relevância das finanças na economia mundial associado à hegemonia política e 
ideológica neoliberal. Nesse sentido, o grande espaço de provisão pública de serviços, criado de maneira heterogênea durante construção do welfare e das políticas sociais em momentos anteriores, e no momento presente sob novas premissas, passa a ser visto como um importante espaço de valorização de capital, ampliação e diversificação das esferas de acumulação, direta ou indiretamente. Assim, o próprio fortalecimento econômico dos mercados de provisão ligados às políticas sociais, associados à mercantilização e às privatizações, mas não exclusivamente a elas, teria ampliado a capacidade política do setor privado em delimitar o formato e conteúdo das políticas sociais e legitimar essas novas conformações nos mais diferentes setores.

\section{Financeirização das políticas sociais no Brasil}

Os reflexos da financeirização nas mudanças recentes nas políticas sociais brasileiras são sensíveis em diversos níveis, embora nem sempre evidentes. A literatura que trata do tema reflete essas dificuldades e o desafio colocado para a compreensão do tema. Atualmente, diversos trabalhos buscam descrever e analisar as transformações aceleradas por que passam as políticas sociais. A maioria dos trabalhos oscila entre uma ênfase excessivamente setorial e tentativas de esboçar interpretações totalizantes que acabam por restringir a compreensão da complexidade de fenômenos abrangentes como a financeirização.

Esta seção busca apresentar um quadro sintético com alguns trabalhos que permitem vislumbrar a situação geral das nossas políticas sociais, em alguns setores importantes, com vista a capturar os principais fenômenos observados nesse campo e encontrar os elementos comuns para enfrentar o desafio de compor interpretações comuns àquelas que se originam no setor da saúde, de que trata a seção seguinte.

Uma das referências atuais sobre as políticas sociais no Brasil é o debate realizado no campo do Serviço Social. Boa parte dos trabalhos recebe a influência do pensamento de Netto (2001), marcado pelo projeto ético-político defendido pelo autor para o Serviço Social, concebendo a assistência social como parte de uma política abrangente de seguridade social.

O pensamento deste campo sobre o capitalismo contemporâneo e as tendências recentes para as políticas sociais é sintetizado por Behring (2011). O eixo central de sua discussão é que as recentes crises do capitalismo têm causado impactos nas expressões da questão social e também na estrutura do mundo do trabalho. As respostas dadas a essas mudanças passam pelo redimensionamento da política social num formato focalizado e assistencialista, afastando-se, portanto, do projeto éticopolítico mencionado acima. Essas respostas têm sido acompanhadas e afetadas pelo que a autora chama de triplo movimento, composto pela contrarreforma do Estado, 
a reestruturação produtiva e a mundialização do capital, que constituem desafios contemporâneos às políticas sociais.

A contrarreforma do Estado consiste no redirecionamento do fundo público para assegurar as condições gerais de produção e reprodução do capital. Este processo reforça uma lógica de custo-benefício para as discussões relativas à proteção social, deixando em segundo plano as discussões sobre os direitos sociais enquanto tais. Esse movimento é acompanhado de um impressionante aumento da apropriação privada do fundo público, seja através da dívida pública seja de outros mecanismos (Behring, 2013).

A reestruturação produtiva afeta as condições para as políticas sociais de pelo menos duas formas. Por um lado, permitindo ao capital ampliar a superpopulação relativa que vive em condições precárias, o que recrudesce a questão social e corrói as condições materiais objetivas. Por outro lado, ampliando a tendência à desorganização política de sindicatos e movimentos sociais. A erosão política e material das organizações dos trabalhadores permitiu que as políticas sociais fossem remodeladas.

Por fim, a financeirização se conecta aos outros movimentos e os potencializa, à medida que permite às empresas pressionar pela desregulamentação trabalhista e ambiental, aproveitando-se da sua capacidade de se mover globalmente sem barreiras e explorar com liberdade e eficiência a força de trabalho.

A ênfase nos impactos desse novo padrão de gestão da riqueza recai sobre a disputa pelo fundo público, ou, mais especificamente, sobre as restrições políticas e econômicas à execução do gasto social, comparativamente a outros gastos correntes dos Estados Nacionais.

Esta problemática é comum a todos os setores das políticas sociais, particularmente para os três pilares do que deveria compor a Seguridade Social segundo a Constituição Federal: saúde, previdência e assistência social.

Uma das referências fundamentais para a compreensão desse processo no Brasil é o trabalho de Salvador (2010). O plano lógico de seus argumentos tenta estabelecer a relação entre financeirização e políticas sociais, através da questão da disputa pelo fundo público, que é foco de seu trabalho.

A linha estabelecida pelo autor parte do contexto de instabilidade internacional (câmbio e juros) provocado pelo novo padrão monetário-financeiro internacional da virada dos anos 1970 para os anos 1980. Considera seus desdobramentos nas crises da dívida na América Latina e destaca as escolhas feitas naquele momento para enfrentar suas consequências. O papel do FMI e do Banco Mundial no processo de negociação da dívida explicaria como essas instituições assumiram o papel de tutores da política econômica da periferia. Dessa forma, 
compreende-se a penetração e influência de suas cartilhas sobre os mais diversos temas na nossa política interna, incluindo o formato da maior parte de nossas políticas sociais.

Entre as consequências da aplicação dessas recomendações está a abertura financeira, consolidada já nos anos 1990. Para os países periféricos, a abertura financeira se tornou a causa de crises. $\mathrm{O}$ autor desenvolve a questão da instabilidade gerada pelos movimentos de capital internacional a partir do trabalho de Lordon (2007) e destaca a pequena representatividade do mercado financeiro brasileiro se comparado ao do volume de operações das finanças mundiais.

Para analisar o caso brasileiro, o autor desenvolve alguns pontos-chave para entender a realidade do país e os condicionantes da trajetória percorrida pelo fundo público no Brasil.

Em primeiro lugar, Salvador (2010) reforça a noção de que toda a nossa estrutura orçamentária, fiscal e tributária está ligada ao contexto pós-Real. Em segundo lugar, demonstra como o arranjo que orienta as políticas macroeconômicas do país pode ser definido como o paraíso dos Bancos. E, por fim, descreve em detalhes como o Orçamento da Seguridade Social (ou orçamento virtual da seguridade social) nunca foi completamente efetivado, mas ainda é fundamental para entender o funcionamento das políticas sociais hoje, ainda que tenhamos uma estrutura híbrida em relação às definições constitucionais.

O trabalho de Salvador (2010) discute, ainda, a constituição parcial dos fundos como definidos pela Constituição Federal de 1988, desde os primeiros anos da nova legislação e, especialmente, sua nova organização depois da Lei de Responsabilidade Fiscal. Por fim, o autor faz considerações sobre os problemas decorrentes dessas deficiências para a efetivação dos direitos sociais que o fundo público deveria, em tese, garantir. A tônica geral é o subfinanciamento crônico das políticas e, para cada setor, as saídas encontradas para lidar com essa condição.

No caso da Previdência, isso gera um cenário muito aquém da universalização dos direitos. No caso da Saúde, como o Fundo Nacional de Saúde não é suficiente para as necessidades do sistema, isso gera uma variedade de formas de articulação entre o público e o privado, ferindo princípios importantes do projeto sanitarista. No caso da Assistência Social, há restrições a programas cruciais para a realidade social brasileira, como os Benefícios de Prestação Continuada (BPC), que atende idosos e deficientes em condições precárias. O subfinanciamento crônico perpetua a dificuldade de executar políticas sólidas com um orçamento robusto e adequado, favorecendo uma forma de gestão focalizada e residual.

Sobre este tema, é importante a contribuição de Lavinas (2013, 2015, 2017), que se refere ao estudo da financeirização das políticas sociais de pagamento do BPC 
e de políticas de fomento ao microcrédito para consumidores individuais de baixa renda promovidas pelo Governo Federal no Brasil no período de 2004 a 2010.

O ponto de partida utilizado pela autora para o estudo da financeirização das políticas sociais do Brasil diz respeito à crítica à adoção, pelo governo, de um modelo de crescimento econômico, a partir de 2004, denominado de convenção pelo crescimento com consumo de massa, ao invés de um modelo baseado no princípio do crescimento com redistribuição.

A autora aponta o ineditismo da estratégia de articulação entre políticas sociais de pagamento de benefícios pecuniários condicionais e expansão da concessão de créditos para trabalhadores de baixa renda como alavanca para o crescimento do mercado de consumo interno. Identifica um fato novo relevante no nível de coordenação estabelecido entre macroeconomia e políticas sociais em geral pelo novo governo a partir de 2004.

A política de aumento incremental do poder de compra do salário mínimo, sua vinculação ao piso de aposentadorias e pensões e a ampliação do universo de beneficiários do BPC não seriam suficientes para alimentar um ciclo de crescimento econômico de longo prazo com consumo de massa sem o desenvolvimento de mecanismos de engenharia social que articulassem o acesso ao mercado financeiro a grupos desprovidos de colaterais em garantia para a concessão de crédito individual. Para esses grupos, o Orçamento Público, pagador de benefícios e avalista da política de valorização do salário passou a ser o garantidor de última linha. A criação do crédito consignado para detentores de emprego formal ou beneficiários da previdência, ao lado da regulamentação do microcrédito ao consumo em geral, seriam o complemento para assegurar o desfecho do objetivo traçado de crescimento com consumo de massa.

Ao analisar a composição do gasto social, cotejando as transferências monetárias com o investimento direto em infraestrutura pública assistencial, Lavinas (2015) identifica uma distorção que se expressa na universalização dos mecanismos de crédito frente às restrições na ampliação do saneamento básico, do acesso à saúde e educação de qualidade, moradia e segurança estabelecidos pela Seguridade Social na Constituição de 1988. A opção pelas transferências monetárias e créditos ao consumo traz implícita a compressão no investimento social para oferta de serviços desmercantilizados de saúde, educação, assistência social e previdência.

O aumento no nível de endividamento das famílias com despesas financeiras e a continuidade da expansão das políticas de concessão de crédito a juros mais altos para rolagem de dívidas não quitadas constituem, segundo Lavinas (2015), uma das faces da financeirização das políticas sociais no Brasil que resulta, ao final, em um mecanismo de transferência de renda dos trabalhadores para os detentores de ativos financeiros. Mais ainda quando se sabe que uma parte importante desses recursos 
emprestados é utilizada para pagamento de serviços de relevância pública como assistência à saúde e educação e não apenas para a compra de bens de consumo.

É na Previdência, maior orçamento da área social, onde os mecanismos de ajuste fiscal podem ter um rebatimento mais regressivo. É essa tendência ao corte de gastos que orienta o grosso das discussões previdenciárias e dá sentido às reformas que vêm ocorrendo. Desde 1988, a Previdência passa por uma série de alterações na sua estrutura institucional e na legislação que estabelece regras de acesso e o cálculo dos benefícios. As principais alterações desde então se concentraram nas Emendas Constitucionais n. 20 (1998) e na Emenda Constitucional n. 41 (2003). As propostas de reforma da previdência foram objeto de muitos trabalhos acadêmicos, entre os quais podemos destacar os artigos organizados por Fagnani et al. (2008).

Conforme descrito por Andrietta (2015), o Sistema Previdenciário Brasileiro passa por um processo de mercantilização, definido como a restrição do acesso ao direito social e expansão da sua oferta como mercadoria. Do ponto de vista dos trabalhadores/contribuintes, esse processo se dá pela combinação de três vetores: o achatamento do Regime Geral da Previdência Social, via redução do valor médio dos benefícios e imposição de obstáculos ao seu acesso; a extinção dos Regimes Próprios de Previdência Social, com o deslocamento dos recursos dos servidores que ganham acima do teto do RGPS para novos fundos de pensão; e a expansão da previdência complementar, tanto em sua modalidade aberta, vendidas pelos bancos, quanto sua modalidade fechada, via fundos de pensão.

Gentil (2006) sustenta, a partir dos dados oficiais do Siafi/Sidor, que a arquitetura fiscal desenhada para financiar os gastos com saúde, previdência e assistência propicia estabilidade e geração de superávits. A autora reconstituiu o Orçamento da Seguridade Social (OSS), partindo da sua definição constitucional, que nunca foi respeitada nem operacionalizada. O OSS é composto, do lado das despesas, por todos os gastos do SUS, os benefícios previdenciários e assistenciais. Do lado das receitas, devem ser consideradas as contribuições previdenciárias de trabalhadores e empregadores, mas também outros tributos criados para esta finalidade, como é o caso da Contribuição Social sobre o Lucro Líquido - CSLL e da Contribuição para o Financiamento da Seguridade Social - Cofins, que são receitas vinculadas à seguridade social $^{7}$. Dessa forma, a autora mostra como a execução do OSS de forma separada do Orçamento Fiscal seria capaz de explicitar a capacidade do sistema de se sustentar a partir da tributação vinculada constitucionalmente, demonstrando porque é possível e necessário afirmar que é falso o discurso de que a Previdência Social brasileira apresenta posição deficitária. Segundo essa interpretação, o Governo Federal seria obrigado a transferir recursos

(7) Os dados, atualizados recentemente pela autora, mostram que o OSS se manteve superavitário, mesmo após a reversão do crescimento desde 2014 (Anfip/Dieese, 2017). 
para cobrir o caixa da Seguridade Social, quando na verdade o que tem acontecido há décadas é exatamente o contrário. Recursos que deveriam ser aplicados para o financiamento da seguridade são, em verdade, transferidos para o governo e, assim, gastos com outras finalidades.

A autora mostra, ainda, como a criação de mecanismos legais para esse desvio de recursos agrava a situação e ajuda a legitimar a posição do governo. $O$ mais explícito desses mecanismos é a Desvinculação das Receitas da União (DRU), um instrumento jurídico que permite que o governo utilize parte das receitas vinculadas para qualquer finalidade. A DRU, que surgiu dentro do escopo do Plano Real, manteve-se por muito tempo em $20 \%$ e foi aumentada para $30 \%$ em 2016, em uma das primeiras ações do governo Michel Temer após a destituição da então presidente Dilma Rousseff da Presidência.

Por fim, Gentil (2006) mostra, a partir de dados e indicadores selecionados, que os gastos sociais, sobretudo com a Previdência, não são explosivos. Embora haja um crescimento dos gastos com benefícios em todas as áreas, ano a ano, para a autora a arquitetura fiscal é capaz de garantir que as receitas acompanhem essas necessidades e permitam a redistribuição do valor gerado pela atividade econômica no país. Mesmo em períodos de crise, quando a arrecadação cai, o resultado do OSS não gera déficits elevados. Esses déficits seriam facilmente controlados se o orçamento fosse respeitado, pois os superávits acumulados nos anos anteriores seriam capazes de dar estabilidade ao caixa da seguridade. Em vez disso, contudo, esse excedente é sistematicamente transferido para a União para arcar com outros gastos correntes.

Essa abordagem é complementar a de Granemann (2006), que destaca que a nova relação entre capital e trabalho tem como um dos seus elementos deslocar parte da massa salarial indireta (poupanças financeiras) para fora da órbita do Estado, encolhendo o Fundo Público e potencializando as receitas e possibilidades de acumulação, tanto dos fundos de pensão, fundos mútuos e instituições bancárias (no caso da Previdência), quanto das empresas e seguradoras ofertantes de saúde, educação, saneamento, habitação, etc. Esse argumento toca diretamente na questão da estratégia das empresas do setor bancário-financeiro no Brasil. Um fenômeno interessante a ser notado é que, pelo comportamento do setor, não é tão relevante a venda direta de previdência privada, numa mera substituição dos regimes de previdência que abriria possibilidades de explorar esse mercado específico. $\mathrm{O}$ fator mais relevante para essas empresas parece ser o deslocamento da massa de recursos imobilizada no fundo público para a esfera financeira e, a partir da disponibilidade desses recursos, potencializar a securitização e a alavancagem de outros negócios diversos. Este motivo parece ser mais relevante que a mera exploração do mercado de previdência complementar privada. 
No campo da educação, destaca-se as pesquisas de Leher (2016) e de outros pesquisadores relacionados, que abordam o tema a partir do aparato conceitual fornecido por Poulantzas, buscando compreender as novas configurações - ou subordinações - da educação no contexto da crescente hegemonia das frações rentistas do capital no bloco no poder (Leher, 2016, p. ix). O autor defende que as novas formas de privatização, comercialização e mercantilização da educação nos últimos 25 anos não podem ser compreendidas sem pesquisas empíricas que adotem uma nova problemática de investigação. Sobretudo, sem estabelecer uma periodização que destaque as descontinuidades em relação a práticas prévias de privatização. Isso inclui o estudo das formas privadas de educação, mas também uma análise de como os empresários da educação influenciam as decisões relativas às políticas educacionais. As pesquisas do grupo compartilham o método que privilegia o plano da luta de classes no Brasil, tanto no que concerne às disputas pela hegemonia entre as frações burguesas (agronegócio, industriais, bancos e outras organizações que operam o capital portador de juros $)^{8}$, quanto pelo choque entre esse projeto dominante e as tentativas de resistência por um modelo de educação público e radicalmente não-mercantil.

Os resultados das pesquisas sobre o caso brasileiro indicam uma coalizão entre as frações dominantes que é liderada pelos bancos e apoiada pelas demais. A conquista da hegemonia pela fração "financeira" remeteria ao processo de renegociação da dívida (anos 1980) e posterior ajuste estrutural, como descrito no mesmo livro por Motta et al. (2016). Esta transição superaria o projeto pedagógico hegemônico anterior, em que se combinavam influências da burguesia industrial, da Igreja Católica e do Movimento Nova Escola. Segundo os autores, hoje a política educacional brasileira responde às influências da ideologia do capital humano, a partir da difusão da noção de capital social. Concretamente, esta influência se expressa pela atuação da organização Todos Pela Educação, estruturada e dirigida pelo grupo Itaú-Unibanco. Esse projeto foi incorporado pelos governos recentes e convertido em política de Estado, como se observa no Plano Nacional da Educação (PNE).

Muitos fenômenos foram registrados pela pesquisa empírica. Em primeiro lugar, a crescente presença de fundos de private equity em todos os níveis do setor de educação privada, num processo de concentração e centralização de capital que diminui o papel de antigas empresas familiares. A formação de grandes grupos, via fusões e aquisições, intensificou-se após a crise de 2008. Em segundo lugar, a erosão das formas públicas de educação, seja pelo crônico subfinanciamento, seja por

(8) O entendimento do capital financeiro enquanto fração de classe, ligado ao capital portador de juros, se distingue da abordagem do tema da financeirização aqui adotada, em que o capital financeiro é precisamente a fusão entre as formas específicas do capital, nos termos discutidos acima, e, portanto, inseparável no plano da análise concreta. O diálogo entre essas diferentes abordagens se faz mais do que necessário, sobretudo quando enriquecido pela pesquisa empírica para a qual este artigo pretende contribuir. 
mudanças na legislação e nas regras internas de funcionamento das instituições que provocam impactos significativos na prática pedagógica dos profissionais envolvidos, notadamente professores. Em terceiro lugar, as profundas alterações nas condições de trabalho e remuneração dos professores, sobretudo pelo aumento da carga horária em sala de aula, redução do tempo de preparação extraclasse, o aumento da insegurança nos regimes de trabalho na iniciativa privada e os impactos de novas ferramentas de ensino à distância nos papéis desempenhados por esses profissionais. Por fim, Leher destaca a transferência massiva de recursos públicos para o setor privado através de mecanismos como o ProUni, o Fies e várias formas de renúncia fiscal. Independentemente das visões e impactos imediatos de cada uma dessas medidas, destaca-se a necessidade de discutir esse fenômeno como parte fundamental de uma nova forma de articulação entre o 'público' e o 'privado'.

O conceito de financeirização também é fundamental para a compreensão do novo paradigma que embasa a política recente de moradia e habitação. $\mathrm{O}$ conteúdo dessa mudança de paradigma é discutido por Rolnik (2013). Essa autora argumenta que, nos anos recentes, se observa uma guinada na agenda das políticas urbanas e de habitação, em nível global, respondendo à influência da globalização e do neoliberalismo. O novo paradigma consiste na retirada dos Estados do setor de habitação e na criação de novos e vigorosos modelos de financiamento de moradias baseados no mercado. Como consequência, a mercadorização da habitação afeta o direito à habitação adequada, processo agravado pela crescente participação dos imóveis como ativos no mercado financeiro global. As preocupações culminam na conclusão de que a nova dinâmica desses mecanismos de mercado se mostrou incapaz de prover moradia adequada e acessível para a população como um todo.

Essa mudança de paradigma passou pelo desmantelamento das políticas de habitação que faziam parte do welfare dos países centrais, enquanto na periferia, especialmente no Brasil, os novos modelos mercantilizados de habitação encontraram um contexto diferente. Por um lado, as escolhas decorrentes da crise dos anos 1980 minaram as possibilidades de execução dos projetos de gasto público em habitação, que já eram incipientes se comparados à dimensão dos problemas. Por outro lado, grandes cidades que haviam recebido intensos fluxos de imigração acomodaram seu déficit habitacional através de diversas formas irregulares de assentamento e autoconstrução, geralmente em áreas sem infraestrutura urbana prévia. A convergência entre as más condições de vida e a violência reforçou o estigma sobre as favelas em geral, e algumas áreas em particular, o que seria utilizado posteriormente dentro da retórica de revitalização que embasaria alguns dos novos projetos de habitação (Rolnik, 2013, p. 1061).

Segundo essa autora, as mudanças responderam a um ambiente definido pela alta mobilidade do capital especulativo, pela guerra dos lugares e pelas restrições fiscais dela decorrentes. Isso alterou profundamente a geografia das cidades, cujo 
efeito mais visível foi a criação de enclaves para grandes projetos, restritos à população de alta renda. Por outro lado, o restante da população sofre com uma força centrífuga provocada pela dinâmica dos preços de imóveis e aluguéis e têm sido deslocadas para áreas desvalorizadas, mais distantes dos equipamentos urbanos e com menor infraestrutura. Ao mesmo tempo que as cidades crescem e recebem elevados montantes de investimentos, esse processo está descolado da melhoria de sua dinâmica urbana (Rolnik, 2013, p. 1063).

Nesse sentido, a autora vê a habitação como um exemplo de que o Estado nunca esteve ausente dos processos que atribuímos ao período neoliberal, mas desempenhou um papel central no processo de financeirização da moradia. Isso foi feito através dos bancos públicos, transferindo recursos de projetos de moradia social para empréstimos pessoais subsidiados. Enquanto isso, o setor financeiro assumiu o controle da indústria da construção civil através da privatização de grandes fundos de investimento, substituindo a construção de imóveis que atendem a necessidades reais imediatas pela construção que atende interesses de investidores (Fix, 2011). O Estado também foi fundamental para legitimar a espoliação direta das pessoas que habitavam áreas irregulares e que foram removidas para dar lugar a empreendimentos privados favorecidos pelo poder público (Rolnik, 2013, p. 1064).

Finalmente, é preciso enfatizar que esses modelos de política urbana não foram capazes de oferecer moradias adequadas e acessíveis para a população como um todo, nem atacar problemas concretos como o déficit habitacional. A crise recente piorou as condições de acesso à terra e à moradia para os estratos mais pobres da população. Como consequência, observa-se uma reação cada vez mais intensa dos grupos atingidos por essas mudanças, em vários lugares do mundo (Rolnik, 2013, p. 1065).

\section{Financeirização da saúde no Brasil}

É consensual no campo da Saúde Coletiva a indicação dos trabalhos de Cordeiro (1980; 1984) e Braga e Gois de Paula (1981) como pioneiros na análise das formas com que os interesses empresariais avançam nos serviços de saúde no Brasil ao longo dos anos 1960-1970, seja consolidando, por meio da política estatal, um complexo médico-empresarial que envolveu empresas de pré-pagamento, setor hospitalar, serviços de exames e tratamentos especializados, indústria farmacêutica e de produção de equipamentos, instrumentos e materiais médicos, incluindo aí a entrada de empresas multinacionais e um forte setor do capital financeiro (Cordeiro 1980; 1984); seja pela forte penetração da empresa privada no modelamento do sistema de saúde, incluindo o padrão de gasto, as formas de financiamento, bem como as articulações entre movimentos dos governos e das políticas financeiras, fiscais e creditícias (Braga; Gois De Paula, 1981). Essas análises contribuíram para a compreensão das interconexões entre o financiamento público e o movimento de 
capitalização da medicina nos anos 1960 e 1970, servindo de material de apoio à construção, pelo movimento sanitário, das bases do novo sistema de saúde que se materializou no Sistema Único de Saúde - SUS.

A inscrição constitucional do SUS e sua implementação, ao longo das últimas três décadas, não foram capazes de conter o aprofundamento da lógica financeira no setor saúde. Os estudos no campo da Saúde Coletiva sobre o desenvolvimento capitalista na saúde, contudo, não acompanharam seu movimento, havendo imprecisões e lacunas quanto à caracterização do fenômeno.

A retomada de estudos sobre o complexo médico-empresarial-financeiro, sobretudo a partir da primeira década de 2000, não desenvolveu o aspecto analítico o possível movimento dos diversos segmentos empresariais da saúde em direção a um padrão de acumulação mais associado à financeirização. Ancorados, seja na teoria dos sistemas complexos (Vianna, 2002), seja em visões desenvolvimentistas (Gadelha, 2003) ou na vertente da teoria crítica da tecnologia (Souza, 2016), tais estudos apresentam uma crítica geral ao avanço da civilização industrial e à racionalidade voltada à acumulação de capital na saúde, mas sua ênfase recai sobre as possibilidades de direcionamento estatal das inovações tecnológicas numa perspectiva social, capaz de conformar um complexo econômico-industrial sensível às exigências da atenção integral à saúde, orientado para a produção e o consumo de tecnologias e serviços inovadores, mais efetivos, seguros e baratos, voltados concomitantemente para a melhoria das condições de saúde individuais e coletivas e para o desenvolvimento inclusivo e sustentável (Souza, 2016, p. S8). O trabalho de Gadelha (2003) aprofunda essa perspectiva, na medida em que concebe o papel do Estado como incentivador da capacidade competitiva das indústrias de saúde para o fortalecimento das políticas nacionais de saúde e de desenvolvimento.

Tal perspectiva orientou, na prática, a política recente de desenvolvimento industrial na saúde, que tem em seus maiores expoentes as Parcerias para o Desenvolvimento Produtivo (PDPs) e o Programa Mais Saúde. A noção de um Estado mediador de interesses públicos e privados em favor do interesse público, contudo, rapidamente se esfacela em conjunturas mais diretamente pautadas por grupos alinhados à lógica da lucratividade. A discussão da financeirização, de todo modo, fica bastante restrita nesta perspectiva de análise.

Andreazzi e Kornis (2008) aportam para o debate da financeirização da saúde com uma reflexão que busca conectar diferentes abordagens teóricas, com vistas a atualizar o pensamento marxista no campo da saúde. Consideram que a atualização do conceito de financeirização implica analisar os fundos de investimento e os fundos de pensão, bem como considerar o segmento produtor de bens do complexo produtivo da saúde e, em especial, a importância da conta de serviços. 
Essa importância é particularmente significativa para as economias capitalistas centrais em função dos dividendos cobrados a título de direitos de patentes, licenciamentos e direitos de propriedade intelectual, pela centralização da pesquisa e desenvolvimento e consequentes inovações (Andreazzi; Kornis, 2008, p. 1417).

Os autores captam as relações entre a lucratividade excepcional das empresas de planos e seguros de saúde, a partir de 2007, e seus movimentos de aquisições, fusões e investimentos, abertura de capital e articulação com bancos de investimentos. Contudo, embora identifiquem a necessidade do aprofundamento de estudos empíricos sobre os movimentos que vêm caracterizando a financeirização da saúde no Brasil, não foram localizados em sua produção posterior resultados neste sentido.

O termo financeirização vem sendo utilizado também nos estudos brasileiros em Saúde Coletiva como ponto de apoio para investigações relevantes sobre a temática do financiamento. Nesse âmbito, Salvador (2010) destaca a importância do estudo do Fundo Nacional da Saúde (FNS) para a compreensão dos principais problemas existentes na saúde brasileira. A partir do estudo de sua constituição, apresenta o modus operandi do subfinanciamento crônico no setor e discute questões que não são propriamente orçamentárias, mas se relacionam diretamente à gestão do fundo público, envolvendo, inclusive, peculiaridades do padrão de articulação público/privada. Entre elas, destacam-se: i) a pequena oferta de infraestrutura assistencial própria no sistema público, que abre espaço para a contratação complementar, sobretudo de leitos hospitalares privados; ii) a fragmentação da gestão do sistema com a proliferação das empresas de direito privado denominadas de Organizações Sociais de Saúde; iii) o problema da dupla porta de atendimento nas unidades assistenciais como barreira de segregação entre usuários de uma mesma unidade; e iv) a precarização geral da concepção sanitarista dentro do modelo assistencial dominante.

Em abordagem semelhante, Mendes e Marques (2009) definem a financeirização como característica central do capitalismo contemporâneo, marcado pela reconfiguração do papel do Estado e pelo asseguramento do pleno crescimento do capital na sua forma fictícia, em detrimento das formas produtivas. $\mathrm{Na}$ área da saúde, o fenômeno é compreendido como determinante da redução de gastos, impondo limites à universalização da assistência pelo SUS.

A crise do financiamento, a partir desse ambiente de dominância financeira, foi explicitada pela adoção de uma política macroeconômica restritiva, resultando em tentativas de diminuição dos gastos na saúde. Não é de estranhar, portanto, que esse esquema do financiamento vem dificultando a efetivação dos princípios do SUS, a universalidade (Mendes; Marques, 2009, p. 844-845). 
Todavia, a visão sobre financeirização restrita ao orçamento público, como uma certa aproximação entre os conceitos de financeirização e neoliberalismo, podem deixar de lado, ou reduzir o potencial explicativo de certos fenômenos empíricos como a valorização das ações, a ampliação dos negócios e o crescimento substantivo da lucratividade de empresas de diferentes segmentos da saúde no país nas primeiras décadas do século XXI, desde o setor de laboratório e diagnóstico, até o varejo farmacêutico, passando pelas empresas de planos e seguros de saúde. Este último segmento foi analisado por Bahia et al. (2016), com base no exemplo da empresa Amil. De acordo com a autora (2016, p. 7):

As mudanças no regime de acumulação da empresa, incluindo a abertura das ações de parte do capital e as aquisições a valorizaram. Entre 2007 e 2012, o número de clientes da principal empresa do grupo, a Amil Assistência Médica Internacional, aumentou de 1.222.617 para 3.496.774. No entanto, a ampliação do capital foi bastante superior ao incremento do número de contratos. Em 2012, a Amil foi comprada pela UnitedHealth, a empresa foi avaliada em R $\$ 10$ bilhões ou US\$ 6,4 bilhões, e o pagamento correspondeu a $60 \%$ do capital de propriedade dos controladores e RS 3,4 bilhões pelas ações na Bovespa.

Num esforço de (re) abertura de caminhos empíricos para a reflexão sobre a financeirização da saúde no Brasil, Bahia (2012) vem desenvolvendo análises sobre os recentes movimentos de aquisições, fusões e abertura de capitais realizados pelas empresas de planos e seguros de saúde, incluindo sua participação no mercado financeiro, considerando, ainda, as conexões entre a agenda política empresarial e as políticas econômicas desenvolvidas no âmbito estatal na primeira década de 2000 . Por meio desta investigação, é possível inferir que a dinâmica de interação públicoprivada nos serviços de saúde pode ser muito mais complexa do que se supõe em algumas análises que estabelecem uma dicotomia entre esses dois setores como compartimentos estanques, a saber, um público e outro privado. Isso significa, pois, que a consolidação, o crescimento e o fortalecimento político de diversos mercados no setor saúde podem constituir um elemento explicativo importante para entender a atual conformação e as contradições das políticas de saúde no Brasil.

\section{Considerações finais}

Nas análises de políticas de saúde as categorias social, privado e público são indissociáveis e incidem sobre uma extensa interface de fenômenos de articulação público/privada onde as ações institucionais de governos determinam e são determinadas por agentes particulares com consequências visíveis sobre bens de relevância pública como a saúde de indivíduos e populações.

$\mathrm{Na}$ assistência à saúde no Brasil, além dos tradicionais grupos econômicos da indústria farmacêutica, de insumos e equipamentos, o setor de serviços 
hospitalares e de intermediação comercial de serviços assistenciais em geral têm se destacado como vetores de difusão da dominância financeira sobre o setor.

As ofertas públicas de ações de empresas de planos de saúde que até os anos 1990 eram controladas por grupos familiares de profissionais da assistência, a participação de agentes econômicos globais por meio de fundos de Private Equity na sua composição societária e o peso relativo de suas respectivas diretorias financeiras na modelagem das estratégias corporativas dos grupos econômicos atuantes na prestação e intermediação da assistência são evidências que revelam a extensão do fenômeno.

A ação política desses atores tem sua expressão institucional na forma de normas regulatórias ad hoc convergentes com seus interesses corporativos e em detrimento das necessidades de saúde e de acesso equitativo ao sistema assistencial dos extratos mais baixos de renda da população, mas, não só isso. A financeirização como novo modo de ser da riqueza global, passa a ter sua expressão particular nas políticas sociais de saúde, que se constituem em um campo extenso de acumulação capitalista cuja base concreta se liga, ao modo de um colateral, a um pilar de reprodução da vida moderna, a assistência à saúde de pessoas e populações.

As modulações necessárias entre as grandes categorias explicativas e os conceitos operacionais mais diretamente relacionados com os casos concretos observáveis em cada formação social são imprescindíveis para que os usos dos recursos teóricos disponíveis para tratar sobre o capital em sua dinâmica atual não se tornem espúrios. Mais ainda quando se verifica que toda uma modelagem institucional concebida sobre a terra arrasada do pós-guerra é confrontada com seus limites diante de um novo modo de ser da riqueza global para o qual certos instrumentos de regulação e controle já não se mostram efetivos.

A opacidade das fronteiras entre o público e o privado, entre as finanças e a produção e outras dicotomias totalizantes de uso corrente tendem a projetar sua sombra sobre uma série de fenômenos de interface não captados pelas categorias operacionais concebidas sob a esfera de determinação de estruturas já fenecidas.

Entre as diversas contradições possíveis, incidentes sobre os interesses mais imediatos de partes do capital em apropriar-se do orçamento público através da oferta geral de serviços, seja via fornecimento de insumos, contratação de serviços ou parcerias público-privadas, poderia ocorrer, por hipótese, se houvesse uma pressão para que os gastos públicos nesses setores aumentassem. Porém, concretamente, nem sempre é isso que ocorre. A privatização por dentro pode ocorrer simultaneamente ao subfinanciamento, como ilustra o caso da assistência à saúde no Brasil.

Da mesma forma, afirmar que o esquema de intermediação assistencial praticado pelos grupos econômicos em atuação no sistema de saúde brasileiro é uma 
estrutura financeirizada pode ser apenas uma tautologia desprovida de potencial heurístico se não pudermos avançar na investigação de como precisamente se expressa esse fenômeno mais amplo na realidade empírica observável. Postulamos que, a meio caminho entre as abordagens unidirecionais que pautam suas explicações exclusivamente sobre ações de governo ou sobre teorias de livre mercado, há um espaço de investigação complexo e multicausal a ser explorado.

Por fim, cabe registrar que se a discussão sobre financeirização no campo da Saúde Coletiva é ainda incipiente, o esforço que se faz necessário é de aprofundamento das pesquisas empíricas e do debate teórico, com vistas a estabelecer nexos entre a financeirização e, por exemplo, o avanço da lucratividade das empresas, sejam elas prestadoras ou intermediadoras de serviços de saúde, produtoras de insumos e medicamentos ou formadoras de trabalhadores na área, por meio de aquisições, fusões e investimentos, abertura de capital, articulação com bancos e fundos de investimentos, articulações políticas etc.

\section{Referências bibliográficas}

ANDRADE, R. P.; PRATES, D. M. Exchange rate dynamics in a peripheral monetary economy. Journal of Post Keynesian Economics, v. 35, n. 3, p. 399-416, 2013.

ANDREAZZI, M. F. S.; KORNIS, G. E. M. Padrões de acumulação setorial: finanças e serviços nas transformações contemporâneas da saúde. Ciência \& Saúde Coletiva, v. 13, n. 5, p. 1409-1420, 2008.

ANDRIETTA, L. S. A mercantilização do sistema previdenciário brasileiro (19882014). Dissertação (Mestrado)-Instituto de Economia/Unicamp, Campinas, 2015.

ANFIP/DIEESE. Previdência Social: reformar para excluir? Previdência: reformar para excluir? Contribuição técnica ao debate sobre a reforma da previdência social brasileira. Brasília: Anfip/Dieese, 2017.

BAHIA, L. et al. Das empresas médicas às seguradoras internacionais de saúde. Cad. Saúde Pública, Rio de Janeiro, v. 32 supl. 2, 2016.

BAHIA, L. Financeirização da assistência médico-hospitalar no Governo Lula. In: MACHADO, C.V.; BAPTISTA, T.W.F.; LIMA, L.D. Políticas de saúde no Brasil: continuidades e mudanças. Rio de Janeiro: Fiocruz, 2012. p. 91-113.

BAMBRA, C. Health status and the worlds of welfare. Social Policy and Society, V. 5, n, 1, 2006.

BAYLISS, K.; FINE, B.; ROBERTSON, M. The role of the state in financialised systems of provision: social compacting, social policy, and privatisation. Geneva, Switzerland: UNRISD, 2013. (UNRISD Working Paper, n. 2). 
BAYLISS, K; FINE, B; ROBERTSON, M. From financialisation to consumption: the systems of provision approach to applied to housing and water. Geneva, Switzerland: UNRISD, 2015. (UNRISD Working Paper, n. 154).

BEHRING, E. Ao marxista impenitente José Paulo Netto. Serviço Social e Sociedade, São Paulo, n. 124, p. 801-804, out./dez. 2015.

BEHRING, E. Desafios contemporâneos das políticas sociais, Revista Katálysis, Florianópolis, v. 14, n. 1, p. 9-10, jan./jun. 2011.

BEHRING, E. França e Brasil: realidades distintas da proteção social entrelaçadas no fluxo da história. Serviço Social e Sociedade, São Paulo, n. 113, p. 7-52, jan./mar. 2013.

BEHRING, E; SALVADOR, E.; BOSCHETTI, I.; GRANEMANN, S (Org.). Financeirização, fundo público e política social. São Paulo: Cortez, 2012.

BELLUZZO, L. G. de M.; ALMEIDA, J. S. G. de. Depois da queda: a economia brasileira da crise da dívida aos impasses do real. Rio de Janeiro: Civilização Brasileira, 2002.

BONIZZI, B. Financialization in developing and emerging countries. International Journal of Political Economy, v. 42, n. 4, p. 83-107, 2013.

BRAGA, J. C. de S. A financeirização da riqueza: a macroestrutura financeira e a nova dinâmica dos capitalismos centrais. Economia e Sociedade, Campinas, v. 2, n. 1, p. 25-57, 1993.

BRAGA, J. C. de S. Crise sistêmica da financeirização e a incerteza das mudanças. Estudos Avançados, São Paulo, v. 23, n. 65, p. 89-102, 2009.

BRAGA, J. C. de S. Financeirização global. O padrão sistêmico de riqueza do capitalismo contemporâneo. In: TAVARES, M. C.; FIORI, J. L. (Ed.). Poder e dinheiro. Uma economia política da globalização. Petrópolis, RJ: Editora Vozes, 1997. p. 195-242.

BRAGA, J. C. de S. Qual conceito de financeirização compreende o capitalismo contemporâneo? In: SÉRGIO, A. B.; SOUZA, R. (Ed.). A grande crise capitalista global 2007-2013: gênese, conexões e tendências. São Paulo: Anita Garibaldi; Fundação Mauricio Grabois, 2015. p. 456.

BRAGA, J. C. S. Temporalidade da riqueza: teoria da dinâmica e financeirização do capitalismo. 1985. Tese (Doutorado)-Instituto de Economia da Universidade Estadual de Campinas. Campinas, 1985.

BRUNO, M. et al. Finance-led growth regime no Brasil: estatuto teórico, evidências empíricas e consequências macroeconômicas. Revista de Economia Política, v. 31, n. 5, p. 730-750, 2011. 
CARNEIRO, R. Desenvolvimento em crise: a economia brasileira no último quarto do século XX. São Paulo: Editora Unesp, 2002.

CHESNAIS, F. Introdução Geral. In: CHESNAIS, F. (Ed.). A mundialização financeira: gênese, custos e riscos. São Paulo: Xamã, 1998.

CORDEIRO, H. A indústria da saúde no Brasil. Rio de Janeiro: Graal, 1980.

CORDEIRO, H. As empresas médicas - as transformações capitalistas da prática médica. São Paulo: Graal, 1984.

COUTINHO, L.; BELLUZZO, L. G. "Financeirização" da riqueza, inflação de ativos e decisões de gasto em economias abertas. Economia e Sociedade, Campinas, n. 11, p. 137-150, 1998.

CROTTY, J. The neoliberal paradox: the impact of destructive product market competition and "modern" financial markets on nonfinancial corporations performance in the neoliberal era. In: EPSTEIN, G. A. (Ed.). Financialization and the world economy. Cheltenham, UK; Northampton, USA: Edward Elgar, 2005. p. 77-110.

EPSTEIN, G. A. Introduction: Financialization and the world economy. In: EPSTEIN, G. A. (Ed.). Financialization and the world economy. Cheltenham, UK; Northampton, USA: Edward Elgar, 2005. p. 3-16.

ESPING- ANDERSEN, G. As três economias políticas do welfare state. Lua Nova, São Paulo, n. 24, set. 1991.

ESPING-ANDERSEN, G. The three worlds of welfare capitalism. New Jersey: Princeton University Press, 1990.

FAGNANI, E.; HENRIQUE, W.; LÚCIO, C. G. (Ed.). Como incluir os excluídos? São Paulo: LTr, 2008.

FARHI, M.; BORGHI, R. A. Z. Operações com derivativos financeiros das corporações de economias emergentes. Estudos Avançados, São Paulo, v. 23, n. 66, p. 169-188, 2009.

FEIJÓ, C.; LAMÔNICA, M. T.; LIMA, S. S. Financialization and structural change: the Brazilian case in the 2000s. Niterói, RJ: UFF. Centro de Estudos sobre Desigualdade e Desenvolvimento, out. 2016. (Texto para Discussão, n. 118).

FINE, B.; SAAD-FILHO, A. Thirteen things you need to know about neoliberalism. Critical Sociology, v. 43, n. 4-5, p. 685-706, 2017.

FINE, B. Financialisation and social policy. In: UTTING, P.; RAZAVI, S.; BUCHHOLZ, R. V.; VARGHESE BUCHHOLZ, R. (Ed.). The global crisis and transformative change. London: Palgrave McMillan, 2012. p. 103-122. 
FINE, B. Financialization and social policy. Presented at the UNRISD Conference on the "Social and Political Dimensions of the Global Crises: implications for developing countries”, Geneva, 12-13 Nov. 2009. (Working paper).

FINE, B. The continuing enigmas of social policy. Geneva, Switzerland: UNRISD, 2014. 59 p. (UNRISD Working Paper, n. 10).

FIORI, J. L. Estado de bem-estar social: padrões e crises. Physis, v. 7, n. 2, 1997.

FIX, M. Financeirização e transformações recentes no circuito imobiliário no Brasil. Tese (Doutorado)-Instituto de Economia, Unicamp, Campinas, 2011.

FLEURY, S. Estado sem cidadãos: seguridade social na América Latina. Rio de Janeiro: Editora Fiocruz, 1994. 252p.

FURTADO, C. A nova dependência, dívida externa e monetarismo. Rio de Janeiro: Paz e Terra, 1982.

GADELHA C. A. G. O complexo industrial da saúde e a necessidade de um enfoque dinâmico na economia da saúde, 2003. Ciênc. Saúde Coletiva. v. 2, p. 521-535, 2003.

GAULARD, M. The Brazilian deindustrialization: financialization is not guilty. Revista de Economia Política, v. 35, n. 139, p. 227-246, 2015.

GENTIL, D. L. A política fiscal e a falsa crise da seguridade social brasileira: análise financeira do período 1990-2005. Tese (Doutorado)-Instituto de Economia, UFRJ, Rio de Janeiro, 2006.

GRANEMANN, S. Para uma interpretação marxista da previdência privada. Tese (Doutorado)- UFRJ. Serviço Social, Rio de Janeiro, 2006.

GUTTMANN, R. Uma introdução ao capitalismo dirigido pelas finanças. Novos Estudos, v. 82, p. 11-33, 2008.

HARTMAN, Y. In bed with the enemy: some ideas on the connections between neoliberalism and the welfare state. Current Sociology, v. 53, n. 1, p. 57-73, Jan. 2005.

HILFERDING, R. El capital financiero. Madrid: Editorial Tecnos, 1973.

HOBSON, J. A. A evolução do capitalismo moderno - um estudo da produção mecanizada. São Paulo: Editora Nova Cultural, 1996.

JENSEN, C. The forgotten half: analysing the politics of welfare services. Int. J. Soc. Welfare, v. 20, p. 404-412, 2011.

KALTENBRUNNER, A. International financialization and depreciation: the Brazilian Real in the international financial crisis. Competition \& Change, v. 14, n. 3, p. 296-323, 2010. 
KARWOWSKI, E.; STOCKHAMMER, E. Financialisation in emerging economies: A systematic overview and comparison with Aglo-Saxon economies. Economic and Political Studies, v. 5, n. 1, p. 60-86, 2017.

LAVINAS, L. 21st Century Welfare. New Left Review, v. 84, Nov./Dec. 2013.

LAVINAS, L. Bolsa-família e Bolsa-banco: a financeirização do social. Insight Inteligência, Ano XVIII, n. 70, p. 69-72, jul./ago./set. 2015.

LAVINAS, L. The takeover of social policy by financialization: the Brazilian paradox. New York: Palgrave Macmillan, 2017.

LAZONICK, W.; O’SULLIVAN, M. Maximizing shareholder value: a new ideology for corporate governance. Economy and Society, v. 29, n. 1, p. 13-35, 2000.

LEHER, R. Commodification: a new problem in education. In: LEHER, R.; ACCIOLY, I (Ed.). Commodifying education: theoretical and methodological aspects of financialization of education policies in Brazil. Rotterdam/Boston/Taipei: Sense Publishers, 2016.

LORDON, F. O eterno retorno da crise financeira. Le Monde Diplomatique Brasil, set. 11, 2007.

MARX, K. O capital - crítica da economia política. São Paulo: Nova Cultural, 1985. v. III, livro terceiro, t. 1.

MENDES, A.; MARQUES, R.M. O financiamento do SUS sob os "ventos" da financeirização. Ciência \& Saúde Coletiva, v. 14, n. 3, p. 841-850, 2009.

MILBERG, W. Shifting sources and uses of profits : sustaining US financialization with global value chains. Economy and Society, v. 37, n. 3, p. 420-451, 2008.

MOTTA, V. et al. Education and financial capital. In Commodification: a new problem in education. In: LEHER, R.; ACCIOLY, I (Ed.). Commodifying education: theoretical and methodological aspects of financialization of education policies in Brazil. Rotterdam/Boston/Taipei: Sense Publishers, 2016.

NETTO, J. P. A construção do projeto ético-político do Serviço Social. Serviço Social e Saúde, Brasília, CFESS/ABEPSS/CEAD/UnB, 2001.

NETTO, J. P. Ditadura e serviço social: análise do serviço social no Brasil pós-64. 8. ed. São Paulo: Cortez, 2005 [1991].

NETTO, J. P.; BRAZ, M. Economia política: uma introdução crítica. São Paulo: Cortez, 2006.

ORHANGAZI, Ö. Financialisation and capital accumulation in the non-financial corporate sector: A theoretical and empirical investigation on the US economy : 1973 - 2003. Cambridge Journal of Economics, v. 32, p. 863-886, Apr. 2008. 
PLIHON, D. As grandes empresas fragilizadas pela finança. In: CHESNAIS, F. (Ed.). A finança mundializada. São Paulo: Boitempo, 2005. p. 133-151.

POWELL, M.; BARRIENTOS, A. An audit of the welfare modelling business. Social Policy \& Administration, v. 45, n. 1, 2011.

ROLNIK, R. Late neoliberalism: the financialization of homeownership and housing rights. International Journal of Urban and Regional Research, Oxford, v. 37, n. 3, p. 1058-1066, May 2013,

ROSSI JÚNIOR, J. L. Hedging, selective hedging, or speculation? Evidence of the use of derivatives by Brazilian firms during the financial crisis. Journal of Multinational Financial Management, v. 23, n. 5, p. 415-433, 2013.

ROSSI, P. Taxa de câmbio e política cambial no Brasil: teoria, intitucionalidade, papel da arbitragem e da especulação. Rio de Janeiro: FGV Editora, 2016.

SALVADOR, E. Fundo público e seguridade social no Brasil. São Paulo: Cortez, 2010.

SERFATI, C. O papel ativo dos grupos predominantemente industriais na financeirização da economia. In: CHESNAIS, F. (Ed.). A mundialização financeira: gênese, custos e riscos. São Paulo: Xamã, 1998.

SERFATI, C. Transnational corporations as financial groups. Work Organisation, Labour \& Globalisation, v. 5, n. 1, p. 10-38, 2011.

SORIA, S. Intersecção de classe: fundos de pensão e sindicalismo no Brasil: Tese (Doutorado)- IFCH-Unicamp, Campinas, 2011.

SÓRIA, S.S. As relações entre sindicalismo e fundos de pensão no governo Lula. In: OLIVEIRA, R.V.; BRIDI, M.A.; FERRAZ, M. O sindicalismo na era Lula: paradoxos, perspectivas e olhares. Belo Horizonte: Fino Traço, 2014.

SOUZA L.E.P.F. Saúde, desenvolvimento e inovação: uma contribuição da teoria crítica da tecnologia ao debate. Cad. Saúde Pública, Rio de Janeiro, v. 32 Supl. 2, 2016.

STOCKHAMMER, E. Financialisation and the slowdown of accumulation. Cambridge Journal of Economics, v. 28, n. 5, p. 719-741, 2004.

TAVARES, M. C.; MELIN, L. E. Pós-escrito 1997: a reafirmação da hegemonia norte-americana. In: TAVARES, M. C.; FIORI, J. L. (Ed.). Poder e dinheiro. Uma economia política da globalização. Petrópolis, RJ: Editora Vozes, 1997.

VAN DER ZWAN, N. Making sense of financialization. Socio-Economic Review, v. 12, n. 1, p. 99-129, 2014.

VIANNA, C. M. M. Estruturas do sistema de saúde: do complexo médico-industrial ao médico-financeiro. PHYSIS: Rev. Saúde Coletiva, Rio de Janeiro, v. 12, n. 2, p. 375-390, 2002. 